\title{
COMPARACIÓN DE DOS TÉCNICAS DE CONCENTRACIÓN VIRAL A PARTIR DE AGUAS CRUDAS DEL DEPARTAMENTO NORTE DE SANTANDER \\ Raquel A. Villamizar ${ }^{1 *}$, Oscar O. Ortíz ${ }^{2}$ \\ 1. Departamento de Microbiología. Facultad de Ciencias Básicas. Universidad de Pamplona. Km 1. Vía Bucaramanga. EC 202. Pamplona, N de S. Colombia. \\ 2. Departamento de Ingeniería Industrial. Facultad de Ingenierías y Arquitectura. Universidad de Pamplona. Km 1. Vía Bucaramanga. EC 202. Pamplona, N de S. Colombia. \\ *Autor de correspondencia: raqvillamizar@unipamplona.edu.co
}

\section{Resumen}

Los métodos de detección de virus entéricos a nivel de laboratorio presentan cierto nivel de complejidad, debido a que estos entes se encuentran muy diluidos en aguas. Esto genera la necesidad de encontrar métodos eficientes que permitan concentrarlos de forma rápida, selectiva, sensible, eliminando interferencias presentes en la matriz y con la certeza de tener partículas virales infecciosas. En este estudio se comparó la ultrafiltración tangencial (UFT) y la separación inmunomagnética (IMS) como técnicas de concentración viral, empleando Rotavirus como modelo. El grado de eficiencia de las mismas fue confirmado empleando la reacción en cadena de la polimerasa acoplada a una reversotranscriptasa (RT-PCR) la cual facilitó la identificación de Rotavirus a partir de aguas crudas en cuatro plantas de potabilización del departamento Norte de Santander, incluyendo sus fuentes de abastecimiento. La UFT se llevó a cabo en un equipo dotado entre otros componentes de membranas millipore de $0.8,0.45$ and $0.22 \mu \mathrm{m}$. Para la IMS se emplearon micropartículas de $2.0 \mu \mathrm{m}$ funcionalizadas con anticuerpos monoclonales anti-Rotavirus. Los resultados permitieron determinar que tanto la IMS como la UFT concentraron eficientemente Rotavirus a partir de agua crudas. No obstante, la IMS exhibió mayor sensibilidad a la hora de comparar la cantidad de RNA viral extraído a partir de cada muestra analizada. Además, está técnica sólo requirió 2 horas para obtener el concentrado viral en comparación de 24 horas empleadas por la UFT. Por tanto, se recomienda emplear para la concentración de virus patógenos presentes en aguas crudas la técnica de separación inmunomagnética. 
Palabras claves: Concentración, virus, agua cruda, filtración, partículas magnéticas

\begin{abstract}
Analytical methods for detecting enteric virus at the laboratory present a certain level of complexity, because viruses are commonly highly diluted in water. This generates the need to find efficient methods that allow them to concentrate in a fast, selective, sensitive way, eliminating background interferences present in the matrix. In this study tangential ultrafiltration (UFT) and immunomagnetic separation (IMS) were compared as viral concentration techniques, using Rotavirus as a model. Their efficiency was confirmed using a molecular biology technique called RT-PCR which facilitated the identification of Rotavirus from raw water in four treatment plants in the Norte de Santander department, including its sources of supply. The UFT was carried out in a using millipore ultrafiltration system coupled to membranes of $0.8,0.45$ and $0.22 \mu \mathrm{m}$. For the IMS $2.0 \mu \mathrm{m}$ microparticles functionalized with monoclonal anti-Rotavirus antibodies were used. The results allowed determining that both IMS and UFT facilitated effectively concentrate Rotavirus from raw water. However, IMS showed greater sensitivity when comparing the amount of viral RNA extracted from each sample analyzed. In addition, this technique only requires 2 hours to obtain the viral concentrate compared to 24 hours employed by the UFT. Therefore, it is suggested to use IMS as method of viral concentration in samples of raw water.
\end{abstract}

Keywords: Concentration, viruses, raw water, filtration, magnetic particles

\title{
Introducción
}

Existe un gran número de virus entéricos que pueden llegar a afectar la salud humana entre los cuales se encuentran los Rotavirus, Norovirus, Sapovirus, Adenovirus, Astrovirus, Enterovirus, Reovirus [1, 2]. El primero de ellos ha sido asociado como la causa más frecuente de diarrea severa en niños a nivel mundial y en países en vía de desarrollo se estima que causa unas 600 mil muertes en 
niños menores de cinco años [3]. Su transmisión se lleva a cabo principalmente por vía oro-fecal, siendo el agua el principal vehículo transmisor [4].

Usualmente, los virus se encuentran muy diluidos en agua ( 1 a $10^{3}$ partículas virales/Lt de agua) $[2,5,6]$, creando la necesidad de pretratamientos de la muestra para poder concentrar las partículas virales. Existen diferentes técnicas de concentración entre las cuales se encuentra la ultrafiltración tangencial (UFT). Esta técnica consiste en realizar una serie de filtrados en membranas millipore de distinto tamaño, dirigiendo la muestra a un filtro de flujo tangencial por medio de una bomba peristáltica de alta presión, produciendo dos fracciones, la filtrada de interés y la excluida por el filtro [7]. Posteriormente, se realiza una segunda ultrafiltración, de donde se obtiene el filtrado final que es analizado a través de técnicas de biología molecular para realizar la respectiva detección del patógeno [8]. No obstante, esta técnica requiere el uso de métodos adicionales a los moleculares para poder determinar el grado de infectividad de las partículas virales concentradas.

Otra técnica de concentración viral es la separación inmunomagnética (IMS), la cual emplea partículas magnéticas acopladas a anticuerpos capaces de detectar, concentrar y separar patógenos. La afinidad existente entre el antígeno y el anticuerpo, los cuales se unen a través de interacciones supramoleculares mediado principalmente por puentes de hidrógenos, uniones iónicas y fuerzas de van der Waals [9] hace que se pueda separar el patógeno de la matriz en la que se encuentre. Este proceso de separación se lleva a cabo mediante la aplicación de un campo magnético, entendido como la región en la que un cuerpo con esta propiedad es capaz de magnetizar las partículas de su alrededor [10]. Aunque es una técnica selectiva, debido al uso de anticuerpos, también se ve altamente afectada por la naturaleza de la matriz, lo que interfiere en su sensibilidad.

Por tal motivo, a través de este estudio se compararon las dos técnicas anteriormente mencionadas, con el fin de encontrar la estrategia más rápida, 
económica, sensible, selectiva, fácil de emplear, que permita la detección de Rotavirus en aguas crudas de 4 plantas de tratamiento del departamento Norte de Santander, incluyendo sus fuentes de abastecimiento.

\section{Materiales y Métodos}

\section{Reactivos}

Se emplearon anticuerpos monoclonales anti-Rotavirus con una concentración de $100 \mu \mathrm{g}$ marca AMSBIO, los cuales fueron en solución buffer salina a una concentración final de $10 \mu \mathrm{g} / \mathrm{mL}(\mathrm{pH} 7.2)$ y almacenados a $-20 \circ \mathrm{C}$ hasta su uso. El buffer fue comprado a Sigma-Aldrich (USA). Las micropartículas magnéticas 1\% $\mathrm{p} / \mathrm{v}$ fueron compradas a Spherotech Inc (USA). Estas fueron disueltas en agua destilada y almacenadas a temperatura ambiente hasta su uso. El Kit QIAamp de QIAGEN (Alemania) fue adquirido para llevar a cabo los procesos de extracción de RNA viral.

\section{Equipos}

Para la separación y concentración viral se empleó un separador magnético manual adquirido en Spherotech Inc. (USA). EI RNA viral fue cuantificado a través de un espectrofotómetro NANODROP 2000 marca Thermo Scientific (USA) y un Sistema Gel Doc ${ }^{\text {tm }}$ XR marca BIO-RAD (USA) fue usado para visualizar los geles del corrido electroforético. Un equipo del Ultrafiltración Tangencial (Millipore) fue empleado para concentrar los virus a partir de muestras de agua.

\section{Muestras de agua cruda}

Se tomaron muestras de $1 \mathrm{Lt}$ de agua cruda y agua potable provenientes de la fase de captación de 4 plantas de potabilización, denominadas de ahora en adelante 001CAR, 002MON, 003TON, 004POR y sus respectivas fuentes de abastecimiento (Río Pamplonita y Río Zulia) localizadas en el Departamento Norte de Santander Colombia. Las muestras fueron tomadas por triplicado en cada planta, en recipientes de plástico estériles y fueron transportadas en neveras 
portátiles provistas de hielo seco hasta el laboratorio para realizar la caracterización virológica.

\section{Funcionalización de las Partículas Magnéticas}

Las partículas magnéticas fueron lavadas tres veces una solución buffer conteniendo (Sodio-Fosfato y 0.05\% Tween-20, pH 7.0). Posteriormente, se centrifugaron y el pellet se expuso a $100 \mu \mathrm{L}$ de una solución de anticuerpos antiRotavirus (10 ppm), los cuales se dejaron reaccionar durante $1 \mathrm{~h}$ a $37^{\circ} \mathrm{C}$ en agitación para favorecer la adsorción de los anticuerpos. Los anticuerpos no unidos fueron removidos mediante lavado tres veces con Buffer sodio-fosfato [11].

\section{Separación Inmunomagnética (IMS) de Rotavirus a partir de aguas crudas}

Una solución de $500 \mu \mathrm{L}$ de partículas magnéticas funcionalizadas con los anticuerpos monoclonales anti-Rotavirus fueron adicionadas a $1 \mathrm{Lt}$ de agua cruda previamente pre-tratada. La interacción antígeno-anticuerpo se llevó a cabo durante 2 horas a temperatura ambiente en agitación constante. Posteriormente, las partículas magnéticas fueron magnetizadas y el sobrenadante fue removido (Figura 1). El magnetizado fue lavado tres veces con solución Buffer fosfato y Tween $0.05 \%$ y agua destilada estéril y se llevó a caracterización molecular.

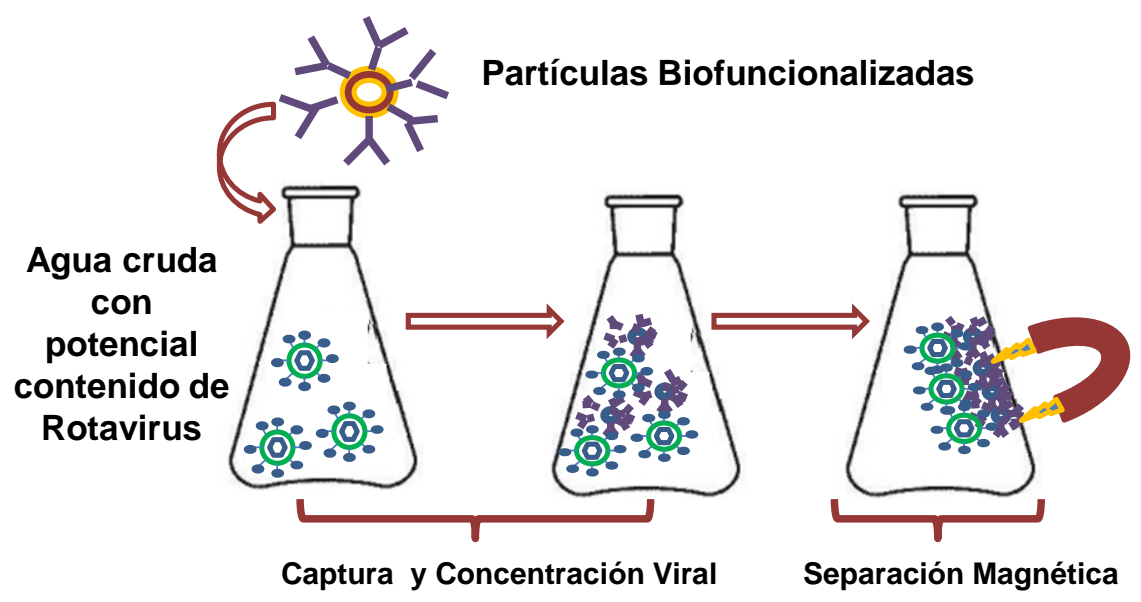

Figura 1. Representación esquemática del proceso de separación inmunomagnética de virus en muestras de aguas crudas. 


\section{Ultrafiltración Tangencial de Rotavirus a partir de aguas crudas}

Esta técnica se llevó a cabo como en tres fases. Primero, se realizó una filtración empleando membranas Millipore de $0.8 \mu \mathrm{m}, 0.45 \mu \mathrm{m}$ and $0.22 \mu \mathrm{m}$. Seguidamente, se aplicó ultrafiltración tangencial empleando un cartucho pre/scaleTFF con tamaño $>10.000 \mathrm{kDa}$. A través de este proceso se obtuvieron dos fracciones, una correspondiente al contenido viral en un volumen final de 100 a $130 \mathrm{~mL}$ y el restante, agua sin filtrar que fue descartado. Posteriormente, se realizó una última ultrafiltración tangencial usando esta vez un cartucho Pellicon XL50 dando como resultado un concentrado final de $6 \mathrm{~mL}$ que se llevó a caracterización molecular. Este procedimiento al igual que la caracterización molecular se llevó a cabo en el laboratorio de Virología del Instituto Nacional de Salud siguiendo los protocolos establecidos por Peláez D y colaborares [12].

\section{Caracterización Molecular}

\section{a. Extracción RNA viral}

La interacción antígeno-anticuerpo se rompió calentando a $95{ }^{\circ} \mathrm{C}$ durante 5 minutos y se enfrío seguidamente a $4^{\circ} \mathrm{C}$. Posteriormente, las micropartículas fueron centrifugadas a $10000 \mathrm{rpm} / 2 \mathrm{~min}$ [11]. El sobrenadante fue usado para llevar a cabo la extracción de RNA viral usando el Kit (Qiagen, Germany). Para tal fin se tomaron $140 \mu \mathrm{L}$ de sobrenadante, el cual aplicando las instrucciones del fabricante, permitió obtener un extracto de RNA final de $60 \mu \mathrm{L}$. Este fue cuantificado a través de espectrofotometría.

\section{b. RT-PCR}

Debido a que el genoma de Rotavirus está basado en RNA ds, previo a la RTPCR éste fue denaturado a $95{ }^{\circ} \mathrm{C}$ durante 5 minutos e inmediatamente fue puesto en hielo por 5 minutos adicionales. La reverso-transcripción fue llevada a cabo a $55^{\circ} \mathrm{C}$ por 30 minutos y luego a $85^{\circ} \mathrm{C}$ por 5 segundos para inactivar la enzima. Los primers empleados fueron rota-sentido positivo (5'-TTGCCACCAATTCAGAATAC3') y rota-sentido negativo (5' ATTTCGGACCATTTATAACC-3') los cuales permitieron amplificar una región de $211 \mathrm{pb}$ correspondientes a un segmento de la proteína VP6 presente en la cápside viral. La amplificación se llevó a cabo 
aplicando 40 ciclos que incluían; denaturación a $95{ }^{\circ} \mathrm{C}$ por 15 segundos, alineamientos a $62{ }^{\circ} \mathrm{C}$ por 1 minutos y extensión a $68{ }^{\circ} \mathrm{C}$ por 5 minutos [13]. Los productos fueron analizados usando electroforesis en gel de agarosa $(1.8 \% \mathrm{p} / \mathrm{v})$.

\section{Resultados}

A nivel de salud pública, los virus entéricos son el grupo de patógenos más críticos, debido a que la dosis mínima infecciosa es muy baja y los virus se encuentran en concentraciones bajas, muy variables, sobretodo en matrices como el agua. Las resultados obtenidos en este estudio permitieron determinar que tanto la UFT como la IMS concentraron Rotavirus a partir de aguas crudas obtenidas de cuatro plantas de potabilización del departamento Norte de Santander, incluyendo sus fuentes de abastecimiento. No obstante, la IMS fue más sensible a la hora de capturar el virus. Esto puede evidenciarse en la figura 2 donde se hace una relación del ARN viral extraido y cuantificado a partir de las muestras de agua recolectadas en cada una de las cuatro plantas de tratamiento, incluyendo su fuente de abastecimiento.



Figura 2. Contenido de RNA viral extraído a partir del concentrado viral obtenido por IMS y UFT en muestras de aguas crudas del departamento Norte de Santander 
La UFT es una técnica que presenta un alto nivel de variabilidad a nivel de concentración viral. En un estudio realizado por Alavandi y colaboradores, tras procesar $100 \mathrm{~L}$ de agua, los investigadores obtuvieron un volumen final de $100 \mathrm{~mL}$ y un rango de recuperación viral que osciló entre un 7.5 a $89.61 \%$ [14]. En la figura 2 se aprecia con claridad que el contenido de RNA viral recuperado empleando UFT es menor al obtenido empleando IMS. Este fenómeno podría atribuirse a que la cantidad de virus presentes en la muestra fue menor a un orden de magnitud con respecto al tamaño de las membranas empleadas en la concentración, generando un rechazo significativo de productos virales durante la filtración [15]. En contraste, la capacidad de recuperación de la IMS se atribuye al uso de anticuerpos monoclonales acoplados a las partículas magnéticas los cuales se unen con alta afinidad al patógeno y por tanto, el contenido de RNA genómico extraído fue mayor.

El genoma viral fue adicionalmente amplificado en gel de agarosa 1,8 \%, permitiendo visualizar bandas características correspondientes a un segmento de 211 pb pertenecientes a la proteína VP6 de la cápside viral de Rotavirus. En la figura 3A se observa los amplicones obtenidos aplicando IMS mientras que en la 3B las obtenidas por UFT, método de referencia empleado por el Instituto Nacional de Salud (INS).

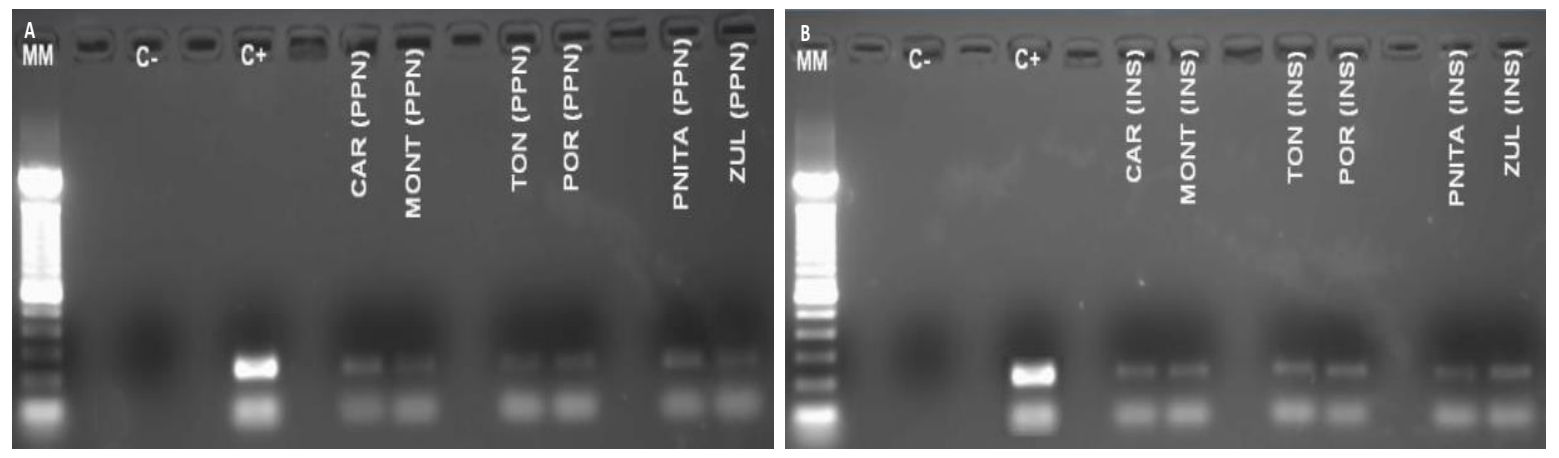

Figura 3. Electroforesis en gel de agarose $1.8 \%$ de Rotavirus empleando A) IMS B) UFT a partir de aguas crudas proveniente de la fase de captación de cuatro plantas de tratamiento así como de su fuente hídrica de procedencia 
La separación inmunomagnética ha sido usada con gran efectividad para separar varios tipos de virus tales como Hepatitis A [16,17], Adenovirus [18], Rotavirus [11] a partir de diferentes muestras ambientales eliminando interferentes, incluido inhibidores de PCR. Estos hallazgos coinciden con lo obtenido en esta investigación, donde lo logra evidenciar en la figura 3A la presencia de Rotavirus en todas las muestras de agua analizadas.

Aunque en este estudio la UFT resultó efectiva en la concentración de Rotavirus a partir de aguas crudas, también podría decirse que la técnica presenta desventajas en su aplicación debido a varios factores. El primero de ellos es el tiempo, entre 6 a 24 horas son requeridas para llevar a cabo el proceso de concentración viral. Adicional al tiempo, se requiere que el método esté acoplado a técnicas de identificación viral que no sólo están basadas en las moleculares. Se requiere el uso de cultivos celulares para determinar el grado de infectividad de las partículas virales, lo cual repercute en costos y manejo por parte de personal altamente calificado.

En el caso de la IMS, se pudo determinar que es una técnica que exhibe gran selectividad y sensibilidad en la detección. Independientemente de la naturaleza de la muestra, es capaz de reconocer el patógeno que se desea detectar y discriminar su presencia, eliminando inhibidores de PCR, lo cual coincide con lo reportado por Yang W y colaboradores y Ha C y colaboradores, [11,17]. El sistema de uso y aplicación es sencillo y rápido, requiriendo tan sólo dos horas para hacer la concentración y separación viral. Además, el empleo de anticuerpos como elementos de reconocimiento, asegura que se detectan partículas virales intactas y por tanto, infectivas sin requerir procedimientos adicionales de identificación. La única desventaja que se detectó es el elevado costo de los anticuerpos monoclonales. No obstante, si se compara el costo de estas biomoléculas, con el que representa los cultivos celulares para identificación después de una UFT, la IMS sería una alternativa viable. 


\section{CONCLUSIONES}

A través de este estudio se logró determinar que la técnica más rápida, económica, sensible, selectiva, fácil de emplear y que permita la detección de Rotavirus en aguas crudas de 4 plantas de tratamiento del departamento Norte de Santander, incluyendo sus fuentes de abastecimiento fue la separación inmunomagnética.

\section{AGRADECIMIENTOS}

Los autores desean agradecer a la Colciencias, por financiación del proyecto a través de la convocatoria 569 al igual que al equipo de trabajo del Laboratorio de Nanotecnología y Gestión Sostenible de la Universidad de Pamplona.

\section{Bibliografía}

1. Ramani S., Cortes N. Hu L, Crawford S, Czako R et al. The VP8* domain of neonatal rotavirus strain G10P binds to type II precursor glycans. Journal of Virology. 2013. 87:7255-7264.

2. Kiulia NM, Hofstra N, Vermeulen L.C., Obara M.A., Medema G and Joan B. Rose. Global Occurrence and Emission of Rotaviruses to Surface Waters. Pathogens. 2015. 4: 229-255.

3. Organización Mundial de la Salud (OMS). 2009. http://www.paho.org/

4. Peláez D, Guzmán BL, Rodríguez J., Acero F., Nava G. Presencia de virus entéricos en muestras de agua para el consumo humano en Colombia: desafíos de los sistemas de abastecimiento. Biomédica. 2015. 36:169-178.

5. Julian, T., Schawb, K. Challenges in environmental detection of human viral pathogens. Current Opinion in Virology. 2012. 2: 78-83

6. Xagoraraki I, Kuo D, Wong K, Wong M and Rose JB. Occurrence of human adenoviruses at two recreational beaches of the great lakes. Applied Environment Microbiology. 2007. 73:7874-81. 
7. Negrete, A., Pai, A., Shiloach, J. Use of hollow fiber tangential flow filtration for the recovery and concentration of HIV virus-like particles produced in insect cells. Journal of Virological Methods. 2014.195:240-246

8. Grzenia D.L., Carlson J.O., Wickramasinghe S.R. Tangential flow filtration for virus purification. 2008. 321:373-380

9. El-Boubbou K., Gruden C., and Huang X. Magnetic glyco-nanoparticles: A unique tool for rapid pathogen detection, decontamination, and strain differentiation. Journal of the American Chemistry Society. 2007. 129:13392-13393

10.Barragán P.E., Gelvez V.M. Efecto de los campos magnéticos y el ultrasonido sobre la calidad microbiológica y las propiedades funcionales en una emulsión de carne de bufalo. Bistua.2013. 11(1):67-76

11. Yang W, Gu AZ, Zeng SY, Li D, He M, Shi HC. Development of a combined immunomagnetic separation and quantitative reverse transcription-PCR assay for sensitive detection of infectious rotavirus in water samples. Journal of Microbiological Methods. 2011. 84: 447-453

12. Peláez D, Rodríguez JA, Rocha EL, Rey GJ. Estandarización de un método de concentración y detección de virus entéricos en agua. Biomédica. 2010. $30: 2$.

13. Tate JE, Rustempasic S, Tam KI, Lyde FC, Payne DC, Szilagyi P, Edwards $\mathrm{K}$ et al. Comparison of 2 Assays for Diagnosing Rotavirus and Evaluating Vaccine Effectiveness in Children with Gastroenteritis. Emerging Infectious Diseases. 2013. 19:1245-1252

14. Alavandi SV, Ananda Bharathi R, Satheesh Kumar S, Dineshkumar N, Saravanakumar C, Joseph Sahaya Rajan J. Tangential flow ultrafiltration for detection of white spot syndrome virus (WSSV) in shrimp pond water. Journal of Virological Methods. 2015. 218:7-13.

15. Stals A, Baert L, Van Coillie E, Uyttendaele M. Extraction of food-borne viruses from food samples: A review. International Journal of Food Microbiology. 2012. 153: 1-9 
16. Lee KB, Lee H, Ha S.D., Cheon D.S. and Choi C. Comparative Analysis of Viral Concentration Methods for Detecting the HAV Genome Using RealTime RT-PCR Amplification. Food and Environmental Virology. 2012. 4:6872.

17. Ha, JH, Choi, C., Ha, SD. Evaluation of Immunomagnetic Separation Method for the Recovery of Hepatitis A Virus and GI.1 and Gll.4 Norovirus Strains Seeded on Oyster and Mussel. Food and Environmental Virology. 2014. 6:290-296.

18. Haramoto E, Kitajima M, Katayama H, Ohgaki S. Real-time PCR detection of adenoviruses, polyomaviruses, and torque teno viruses in river water in Japan. Water Research. 2010. 44:1747-1752 